\title{
CZY ZMIERZAMY W STRONĘ MCARCHIWUM? ARCHIWA A MAKDONALDYZACJA
}

\section{Słowa kluczowe}

archiwa, archiwa państwowe, makdonaldyzacja, procesy społeczne, społeczeństwo, standaryzacja, retrokonwersja

\section{Keywords}

archives, state archives, McDonaldization, social processes, society, standardization, retroconversion

\section{Streszczenie}

Artykuł zatytułowany „Czy zmierzamy w stronę McArchiwum? Archiwa a makdonaldyzacja” porusza zagadnienie wpływu zjawiska makdonaldyzacji na funkcjonowanie archiwów, w tym przede wszystkim archiwów państwowych. Pierwsza część artykułu

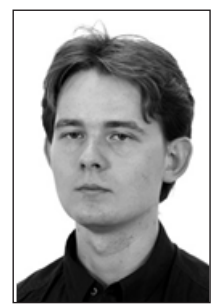

Hadrian Ciechanowski jest doktorem nauk humanistycznych oraz pracownikiem Archiwum Państwowego w Toruniu. Jego zainteresowania badawcze koncentrują się na zagadnieniach związanych z archiwistyką i historią biurokracji. Oprócz zagadnień uznawanych za klasyczne, nie stroni od podejmowania tematów z pogranicza archiwistyki i innych dziedzin, w tym m.in. z zakresu antropologii archiwistyki.

E-mail: ciechanowski.hadrian@wp.pl

ORCID ID: 0000-0002-4913-3600 
przybliża czytelnikom zjawisko opisane przez Georga Ritzera, które następnie zostało odniesione do wybranych aspektów rozwoju archiwów w Polsce i na świecie.

\section{Summary}

Are we heading toward McArchives? Archives and McDonaldization

The article touches the issue of the impact of McDonaldization on archives, especially state archives. The first part of the article presents the phenomenon of McDonaldization, described by George Ritzer. Later, the phenomenon was applied to chosen aspects of archives development in Poland and around the world.

$\mathbb{N}$ Ta przestrzeni dziejów społeczeństwa ulegały zmianom w następstwie nowych prądów filozoficznych, wynalazków czy zjawisk gospodarczych. Zmiany te od wieków wywierają wpływ także na instytucje będące wytworami społeczeństw. Celem poniższego artykułu jest spojrzenie na rozwój archiwów poprzez pryzmat makdonaldyzacji, opisanej w 1993 r. przez amerykańskiego socjologa Georga Ritzera w książce pt. Makdonaldyzacja społeczeństwa, w której autor zaprezentował sformułowaną przez siebie teorię makdonaldyzacji. Zjawisko to można zdefiniować jako: „proces, który powoduje, że w coraz to nowych sektorach społeczeństwa Stanów Zjednoczonych, a także reszty świata zaczynają dominować zasady działania baru szybkich dań"1. Proces ten autor wywodził z szeregu zjawisk, jakie miały miejsce od przełomu XIX i XX w. W kontekście archiwów warto bliżej przyjrzeć się niektórym z nich. Zdaniem Ritzera jedną z podstaw procesu makdonaldyzacji była biurokratyzacja i wiążąca się z nią racjonalizacja, którą badał i opisywał Max Weber ${ }^{2}$. Wiązał on ją jednak wyłącznie ze społeczeństwem okcydentu, który jako jedyny wykształcił tzw. racjonalność formalną oznaczającą, że w swoich poszukiwaniach optymalnego środka do określonego celu ludzie opierają się na zasadach, przepisach i dużych strukturach społecznych. Racjonalność formalna pozostawiała zatem jednostce niewielką możliwość wyboru środka do osiągnięcia obranego celu ${ }^{3}$. Za strukturę, która najlepiej odpowiadała racjonalności, Weber uważał biurokrację, w której widział strukturę najsprawniejszą przy wykonywaniu wielu zadań wymagających tzw. papierkowej roboty. Ponadto, biurokracje starają się jak najwięcej rzeczy

${ }^{1}$ G. Ritzer, Makdonaldyzacja społeczeństwa, Warszawa 2009, s. 14.

2 Zob. m. in. M. Weber, Gospodarka i społeczeństwo, zarys socjologii rozumiejącej, Warszawa 2002.

${ }^{3}$ G. Ritzer, dz. cyt., s. 50 . 
kwantyfikować, dzięki czemu po sprowadzeniu działań do serii zadań łatwiej ocenić ich wydajność. Nadto biurokracje - dzięki głęboko wszczepionym zasadom i przestrzeganiu przepisów - działają w sposób wysoce przewidywalny. Wreszcie kładą one nacisk na sterowanie ludźmi poprzez zastępowanie ich osądu dyktatem zasad, przepisów i struktur ${ }^{4}$.

Kolejnym poprzednikiem makdonaldyzacji było tzw. naukowe zarządzanie, czyli szukanie jednej i najlepszej metody wykonywania określonych zadań. Twórca naukowego zarządzania - Frederick Winston Taylor opracował szereg zasad mających na celu racjonalizację pracy. Będąc przekonanym o nieskuteczności metod pracy amerykańskich robotników, starał się je zastąpić najlepszą metodą - polegającą na stosowaniu środków optymalnych z punktu widzenia celu. Istotna dla osiągnięcia przewidywanych efektów była również przewidywalność, która polegała na tym, by pracę przy wykorzystaniu opracowanej metody mógł wykonywać każdy robotnik, w tym również nieposiadający określonego przygotowania. Naukowe zarządzanie prowadziło tym samym do całkowitej normalizacji narzędzi i procesów produkcyjnych. W praktyce sprowadzało się to do wykonywania przez pracowników jednej lub maksymalnie kilku powtarzających się czynności, przy wykorzystaniu z góry określonych narzędzi ${ }^{5}$.

Naukowe zarządzanie ściśle wiąże się z kolejnym zjawiskiem, które doprowadziło do powstania makdonaldyzacji, czyli wprowadzonej przez Henry'ego Forda taśmy montażowej. Wdrożenie tego wynalazku miało na celu podniesienie wydajności produkcji oraz ujednolicenie produktu końcowego. Taśma montażowa pozwala bowiem na kwantyfikację wielu elementów procesu produkcyjnego i zwiększenie liczby wyrobów, jednocześnie pozwala ona także na poddanie robotnika maksymalnej kontroli. Kiedy nie wykona on określonej czynności, od razu widać to na produkcie końcowym. Przykładowo, w samochodzie brak kołpaków. Ze względu na ograniczony czas na wykonanie kolejnych zadań praktycznie niemożliwa jest również zmiana sposobu ich wykonywania. Jednocześnie zaprogramowane czynności mogą być wykonywane niemal przez każdego bez względu na jego umiejętności czy predyspozycje ${ }^{6}$.

Ostatnim etapem na drodze do makdonaldyzacji było powstanie barów McDonald's. Pierwszy lokal tych popularnych barów szybkich dań został otwarty w 1937 r. przez braci Maca i Dicka McDonaldów w kalifornijskiej Pasadenie. Bracia w swojej restauracji przyjęli trzy zasady: duża szybkość, duża ilość i niska cena.

\footnotetext{
4 Tamże, s. 51-52 oraz M. Weber, dz. cyt., s. 166-168.

${ }^{5}$ G. Ritzer, dz. cyt., s. 58-61.

6 Tamże, s. 61-64.
} 
W związku z tym zaproponowali bardzo ograniczone menu, a do przygotowania serwowanych dań stosowali zasady działania taśmy montażowej. „Dzięki skromnemu menu mogli rozbić proces przygotowania jedzenia na proste, powtarzalne czynności, których potrafili się szybko nauczyć nawet ci, co do barowej kuchni weszli pierwszy raz" " „Opracowali przepisy dyktujące co pracownicy mają robić, a nawet co mają mówić" . Rozwój sieci przyspieszył jednak dopiero od lat 50. XX w., kiedy Ray Kroc - najpierw jako wspólnik i agent braci, a następnie samodzielny właściciel - zaczął udzielać franczyz na prowadzenie barów McDonald's. W swoich działaniach połączył on zasady działania stosowane we franczyzach (znanych już wcześniej) z regułami biurokracji, naukowego zarządzania oraz taśmy montażowej. Dzięki takiemu podejściu rozbudował firmę najpierw na skalę krajową, a następnie światową ${ }^{9}$. Obecnie sieć posiada ponad 37 tys. restauracji w ponad stu krajach na świecie ${ }^{10}$, w samej Polsce są 403 restauracje w ponad 150 miejscowościach ${ }^{11}$.

W tym miejscu poczynić należy jeszcze jedną uwagę dotyczącą zjawiska makdonaldyzacji. Wbrew nazwie pochodzącej od sieci fast food nie dotyczy ona wyłącznie tej sieci lub nawet branży gastronomicznej jako takiej. Zjawisko to dotyka rożnych (prawdopodobnie wszystkich) dziedzin życia społecznego. Nazwa została zaczerpnięta od barów McDonald's, ponieważ zdaniem Georga Ritzera w takiej formie najlepiej brzmi ${ }^{12}$.

Na podstawie analizy zjawisk stojących u podstaw makdonaldyzacji można wskazać jej najważniejsze aspekty. Zgodnie z tym, co wskazywał Ritzer, są to:

1) sprawność rozumiana jako optymalna metoda docierania z punktu do punktu (w sprawnej organizacji pracownicy wykonują kolejne etapy według ustalonego z góry procesu);

2) wymierność, czyli przywiązywanie szczególnej wagi do ilościowych cech sprzedawanych produktów (wielkość, porcja, cena) i świadczonych usług

7 J.F. Love, McDonald's: Behind the Arches, Toronto, 1986, s. 18, za: G. Ritzer, dz. cyt., s. 69-70.

8 J.F. Love, dz. cyt., s. 20, za G. Ritzer, dz. cyt., s. 70.

9 Tamże, s. 69-74.

10 McDonald's Reports Fourth Quarter And Full Year 2018 Results And Quarterly Cash Dividend, https://mcdonaldscorporation.gcs-web.com/news-releases/news-release-details/mcdonalds-reports-fourth-quarter-and-full-year-2018-results-and (dostęp: 04.02.2019).

${ }^{11}$ Informacje o firmie. McDonald's $w$ Polsce: 403 restauracje $w$ ponad 150 miejscowościach, ponad 22500 pracowników i pót miliona gości każdego dnia, https://mcdonalds. pl/files/McDonalds_-_informacje_o_firmie.pdf?368. (dostęp: 04.02.2019 r.).

12 G. Ritzer, dz. cyt., s. 10-11. 
(czas oczekiwania na produkt). W systemach zmakdonaldyzowanych dostarczanie czegoś w dużej ilości albo szybko oznacza, że to musi być dobre;

3) przewidywalność rozumiana jako pewność, że wyroby i usługi będą zawsze takie same;

4) sterowanie przejawiające się najczęściej w tym, że poprzez stworzone procedury oraz specjalnie przygotowane otocznie steruje się zachowaniem ludzi. Sterowaniu podlegają zarówno pracownicy, jak i klienci, którzy często nie zdają sobie z tego sprawy. W celu zwiększenia sterowania pracowników zastępuje się również stopniowo środkami technicznymi ${ }^{13}$.

Makdonaldyzacja (postępująca racjonalizacja) posiada pewne zalety, które doprowadziły do jej ogólnoświatowego sukcesu. Dzięki jej wpływowi większa część społeczeństwa ma dostęp do większej liczby towarów i usług. Zastosowanie metod racjonalizacji zmniejsza zależność dostępności towarów i usług od czasu i miejsca, jednocześnie umożliwia dostarczanie towarów prawie natychmiast i znacznie wygodniej niż kiedyś. Ujednoliceniu uległa także jakość towarów i usług oraz zwiększyła się dostępność ich ekonomicznych wersji. Zmiany te pozwoliły ludziom pracującym dłużej i mającym mniej wolnego czasu korzystać z usług szybko i sprawnie. Zmakdynaldyzowane instytucje stają się także ostojami stabilności, ponieważ niezależnie od miejsca na świecie i różnic kulturowych pozostają jako znajome i bezpieczne miejsca. Natomiast kwantyfikacja produktów pozwala konsumentom porównywać konkurujące ze sobą produkty. Niektóre towary dzięki ich wytwarzaniu w systemie podlegającym starannej kontroli są także bezpieczniejsze. W systemach zmakdonaldyzowanych, w których obowiązują jednakowe zasady, ludzie mogą częściej spodziewać się równego traktowania. Wreszcie dzięki sieciom działającym na wspólnych zasadach szybciej upowszechniają się innowacje organizacyjne i techniczne, a najpopularniejsze produkty jednej kultury łatwiej przenikają do innych ${ }^{14}$.

Co oczywiste, systemy silnie zracjonalizowane mają także pewne wady. Przede wszystkim zbyt wielkie zracjonalizowanie prowadzi do nieracjonalności, a często jest także dehumanizujące. Pozostając w obszarze barów szybkich dań, wskazać można m.in. takie negatywne aspekty, jak niesprawność, której wyrazem są długie kolejki do kasy, a także wysokie koszty wytworzenia produktu, który jest zdecydowanie tańszy, gdy przygotuje się go w domu. Kwantyfikacja

\footnotetext{
13 Tamże, s. 30-35.

14 Tamże, s. 35-36.
} 
i zwracanie zbyt dużej uwagi na czynniki ilościowe prowadzić może do bardzo niskiej jakości wykonywanej pracy, której nikt nie kontroluje. Konsekwencją postępującej racjonalizacji jest także dehumanizacja. Odczłowieczenie polega w pierwszej kolejności na tym, iż człowieka sprowadza się do roli „robota”, który ma wykonywać wyłącznie określone zadania przypisane do jego miejsca pacy, a także na ograniczaniu jego wyboru tylko i wyłącznie do możliwości wskazanych przez obowiązujące procedury. W systemach silnie zracjonalizowanych następuje również stopniowe zastępowanie rzeczywistych relacji pomiędzy ludźmi ich zrytualizowaną formą, która polega w dużej mierze na tzw. iluzji bliskości opierającej się na odgrywaniu z góry zaprogramowanych ról. Dążenie do coraz większej sprawności i przewidywalności prowadzi w konsekwencji do zastępowania człowieka i kontaktów międzyludzkich maszynami oraz interakcjami zachodzącymi na linii: człowiek-maszyna ${ }^{15}$.

Największym zagrożeniem wiążącym się z racjonalizacją jest jednak wpadnięcie społeczeństwa w pułapkę racjonalności, w której ludzie mogą się poruszać wyłącznie pomiędzy systemami zracjonalizowanymi. Ze zracjonalizowanych instytucji edukacyjnych przechodziliby do zracjonalizowanych miejsc pracy, z nich do zracjonalizowanych miejsc rekreacji, a następnie do zracjonalizowanych domów ${ }^{16}$. Choć problem ten nie należy do zakresu niniejszego artykułu, na marginesie tych rozważań warto jednak zadać sobie pytanie, czy w rzeczywistości ludzkość nie wpadła już w tę pułapkę?

Wciąż jednak brak odpowiedzi, w jaki sposób postępująca makdonadyzacja przekłada się na dziedzinę archiwalną, a w szczególności na archiwa państwowe? Jak się zdaje, archiwa po raz pierwszy wkroczyły na drogę racjonalizacji wraz z pojawieniem się pierwszych zasad rządzących konstrukcją ich zasobu. Zasada pertynencji rzeczowej, a następnie zasady poszanowania zespołu archiwalnego i proweniencji doprowadziły do unifikacji układu archiwaliów w archiwach na całym świecie. Znaczy to ni mniej ni więcej, że użytkownik, w jakimkolwiek kraju by się znalazł, może spodziewać się podobnej struktury zasobu archiwalnego. W większości państw świata natrafi on bowiem na zespoły archiwalne odpowiadające instytucjom, organizacjom czy urzędom działającym na danym terenie. Pogłębieniem procesu rozpoczętego przez pojawienie się ogólnych zasad było wprowadzenie międzynarodowych standardów opisu archiwalnego, które poza ujednoliceniem struktury światowego zasobu archiwalnego miały na celu także

\footnotetext{
15 Tamże, s. 212-249.

16 Tamże, s. 53-54.
} 
unifikację jego opisu ${ }^{17}$. Wprowadzane zasady oraz międzynarodowe standardy były zatem wyrazem dążenia do coraz większej przewidywalności. Dzięki nim, niezależnie od szerokości geograficznej, użytkownik powinien nie tylko umieć poruszać się w zasobach danego archiwum, ale również niezależnie od systemu opisu, zarówno analogowego, jak i cyfrowego, otrzymywać informacje o podobnej formie i głębi, które dzięki temu powinny być dla niego bardziej czytelne.

Następnym przykładem wpływu racjonalizacji na funkcjonowanie archiwów państwowych są stopniowo wprowadzane wskazówki metodyczne obejmujące coraz większą część zespołów wytwarzanych przez różne grupy urzędów. Wskazówki metodyczne, oczywiście gdyby stosować je ściśle, powinny maksymalnie ograniczyć wpływ archiwisty na opracowanie zespołu, bowiem w swojej pracy powinien on w zasadzie ograniczyć się do wyboru metod zaproponowanych odgórnie. Własna inwencja twórcza archiwisty powinna zatem objawiać się tylko przy odrębnościach występujących w poszczególnych zespołach. Ścisłe trzymanie się wskazówek prowadziłoby do większej przewidywalności otrzymywanych wyników wyszukiwania oraz podnosiło sprawność działania archiwistów, a przez to także samej instytucji. Przewidywalność byłaby jeszcze większa, gdyby do rzeczywistego stosowania weszły proponowane swego czasu tezaurusy. Im większe ujednolicenie stosowanego języka, metod opisu i opracowania, tym większe ujednolicenie otrzymywanych wyników wyszukiwawczych, a także teoretycznie większa sprawność ich uzyskiwania. W dążeniu do coraz większej sprawności archiwa państwowe poszły znacznie dalej wraz $\mathrm{z}$ wprowadzeniem komputerowych baz danych, a następnie systemu ZoSIA. Na tej drodze archiwa zaszły już na tyle daleko, że nastąpiła przynajmniej częściowa dehumanizacja całego procesu. Człowiek został skrępowany środkami technicznymi wymuszającymi określone zachowanie i wybory (m.in. poprzez zastosowane pola i ograniczane przez nie możliwości wyboru). Prawdopodobnie najbardziej znaczącym dowodem wpływu racjonalizacji na proces opracowania jest zdanie zawarte w protokole z posiedzenia Centralnej Komisji Metodycznej z dnia 7 listopada 2018 r., w którym stwierdzono, że: „CKM będzie zapleczem metodycznym dla nowej wersji systemu ZoSIA"18. Zgodnie z tym twierdzeniem

17 Na temat standardów zob. np. A. Laszuk, Standardy Międzynarodowej Rady Archiwów - od praktyki do teorii? [w:] Toruńskie Konfrontacje Archiwalne, t. 2: Teoria archiwalna wczoraj - dziś - jutro, red. W. Chorążyczewski, A. Rosa, Toruń 2011, s. 227-246.

18 Protokót z posiedzenia Centralnej Komisji Metodycznej, Warszawa, 7.11.2018 r., https://www.archiwa.gov.pl/files/Protokol_posiedzenia_CKM_7_11_2018.pdf (dostęp 04.02.2019). 
Centralna Komisja Metodyczna nie służy już archiwistom ani nawet archiwom czy Naczelnemu Dyrektorowi Archiwów Państwowych, ale samemu systemowi, który w jakiejś mierze, w wyniku odczłowieczenia, stał się celem samym w sobie.

Jednym z przejawów sterowania $\mathrm{w}$ archiwach jest natomiast stosowanie regulaminów. Choć obowiązujące regulaminy nie wyznaczają bardzo sztywnych ram postępowania pracowników i użytkowników, to jednak w dużej mierze rządzą interakcjami zachodzącymi w czytelniach. Zarówno przepisy centralne jak i obowiązujące w poszczególnych archiwach wyznaczają drogę, którą należy przebyć, aby otrzymać materiały archiwalne. Użytkownik zobowiązany jest do wypełnienia zgłoszenia oraz rewersu. Pracownik musi natomiast udzielić mu odpowiednich informacji, dopilnować przejścia przez użytkownika drogi biurokratycznej oraz, o ile się to udało, zaserwować mu wybrane przez niego jednostki archiwalne. Jednocześnie ograniczony jest wybór formy, w jakiej użytkownik chciałby skorzystać z archiwaliów, ponieważ gdy archiwum posiada ich kopie użytkowe, jest zobowiązany udostępniać właśnie je ${ }^{19}$.

Nieco „sztywniejsze” procedury występują w archiwach, które - jak np. Archiwum Państwowe w Bydgoszczy - zarządzają tym procesem za pomocą środków technicznych. Użytkownik przez cały proces przechodzi, mając „kontakt” jedynie z maszyną. Archiwista w pracowni jest w dużej mierze stróżem i ekspedientem, który ma dopilnować porządku oraz udzielić pomocy tym konsumentom, którzy sami mają problem z „wejściem w jego buty” za pomocą dostępnych środków. Nasuwające się w tym miejscu skojarzenie to supermarket, w którym konsument najpierw sam wykonuje pracę sprzedawcy, wkładając zakupy do koszyka, a następnie osobiście pełni rolę kasjera i pakowacza, gdy korzysta z kasy samoobsługowej. Zastosowanie określonych procedur, oczywiście poza aspektem dehumanizującym, pozwala jednak użytkownikowi spodziewać się podobnego traktowania - niezależnie od tego, w którym archiwum się znalazł. Wraz z rozwojem modułu w systemie ZoSIA, który ma pomóc w zarządzaniu procesem udostępniania, można się spodziewać dalszego pogłębienia zasygnalizowanych procesów.

Innym aspektem sterowania w archiwach są możliwości, jakie daje zastosowanie systemów ZoSIA oraz klasy EZD. Dzięki środkom technicznym możliwe jest stałe kontrolowanie ilości pracy wykonywanej przez archiwistów. Dyrektor

19 Zarządzenie nr 24 Naczelnego Dyrektora Archiwów Państwowych z dnia 18 maja 2017 r. w sprawie organizacji udostępniania materiałów archiwalnych w archiwach państwowych, § 6 ust. 3, https://www.archiwa.gov.pl/files/Zarzadzenie_NDAP_18_5_2017. pdf (dostęp 22.06.2019). 
czy kierownik może kontrolować rodzaj, szybkość i ilość zadań wykonywanych przez poszczególnych archiwistów. Jednocześnie naczelnym kontrolerem stało się Narodowe Archiwum Cyfrowe i pośrednio Naczelna Dyrekcja Archiwów Państwowych, które dzięki podglądowi wszystkich archiwów mogą sprawować stałą kontrolę nad ich działaniem, a poprzez to sterować podejmowaną przez nie aktywnością.

Do tej pory wskazanych zostało kilka aspektów makdonaldyzacji w archiwach związanych ze sprawnością, przewidywalnością oraz sterowaniem. W związku z tym należy poruszyć także problemy związane z zagadnieniem wymierności. W ciągu kilku ostatnich lat przed ukazaniem się niniejszego artykułu aspekt ten sprowadzał się w głównej mierze do realizacji programu retrokonwersji. Metody wdrożone przez Naczelnego Dyrektora Archiwów Państwowych dra Wojciecha Woźniaka całkowicie koncentrowały się na wytworzeniu w krótkim czasie dużej liczby dóbr (opisów archiwalnych). Rozliczanie wykonania zadania polegało natomiast na sprawdzaniu ilościowych wskaźników produkcji, czyli liczby wprowadzonych rekordów. Zupełnego znaczenia nie miało natomiast to, jaka jest jakość tych rekordów, co wyrażali w swoich wypowiedziach także przedstawiciele Naczelnej Dyrekcji Archiwów Państwowych i Ministerstwa Kultury i Dziedzictwa Narodowego, którzy wprost twierdzili, że użytkownik woli dostać produkt gorszej jakości, ale szybko i w dużej ilości. Czyż nie jest tak w dowolnej sieci barów szybkiej obsługi? Dążenie to przejawiało się także w pędzie do udostępniania jak największej liczby skanów materiałów archiwalnych online. Także w tym przypadku użytkownik może otrzymać produkt oferowany przez archiwa szybko, wygodnie i w dużej ilości. Czyż nie jest to jednak produkt w jakiś sposób pośledni? Pozbawiony tego ulotnego aspektu, który pozwala użytkownikowi nawiązać kontakt z historią. Gdyby pokusić się o porównanie do branży gastronomicznej, należałoby stwierdzić, że to porównywalne do relacji między burgerem z dobrej restauracji a hamburgerem z McDonalda. Wnioski wynikające z tego porównania narzucają się same...

Jednocześnie serwowanie użytkownikom dużych ilości archiwalnych produktów za pomocą zdehumanizowanych środków technicznych, zastępujących archiwistę z działu opracowania oraz tego z czytelni, a także magazyniera, prowadzi do powstania nieracjonalności. Wraz ze wzrastającym ruchem zmniejsza się przepustowość serwerów, zwiększając jednocześnie czas oczekiwania na otrzymanie wyników. Niska jakość wielu opisów powoduje natomiast, że otrzymywane wyniki są w dużej mierze nierelewantne, a użytkownikowi ciężko dotrzeć do sedna swoich poszukiwań. Nie dość więc, że prowadzi to do niesprawności, to także w pewnym stopniu powoduje zaprzeczanie celowi 
przyświecającemu całemu systemowi. Ostatecznie archiwa i archiwalia zostają pozbawione swojej „magiczności” płynącej z niepowtarzalnego klimatu i bliskości historii. W efekcie stają się kolejnymi instytucjami, które mają zapewnić produkt szybki, łatwo strawny i pozbawiony głębi, ale za to odpowiadający gustom współczesnego konsumenta.

Jak zatem należałoby odpowiedzieć na pytanie postawione w tytule artykułu? Nawet na podstawie powyższej (wstępnej) analizy można wyciągnąć wniosek, że archiwa (w tym przede wszystkim szeroko rozumiane archiwa państwowe) stopniowo zmierzają w stronę funkcjonowania w formule „McArchiwum”. Proces ten posiada dobre oraz złe strony, na co wskazują przykłady zaprezentowane wcześniej. Niezależnie od oceny zachodzących zmian wydaje się, że jest to proces nieuchronny, wymuszany przez samo społeczeństwo, które zamknięte w żelaznej klatce racjonalności oczekuje coraz to kolejnych jej przejawów, czego ofiarą będą ostatecznie także archiwa. Dzisiaj instytucje te są stosunkowo mało zracjonalizowane, a archiwiści często nie zdają sobie sprawy z tego, jaki wpływ na ich miejsce pracy wywierają procesy społeczne. Ale co będzie za 10, 20 czy 50 lat, kiedy zmianie ulegnie także sposób myślenia pokoleń urodzonych i wychowanych w zracjonalizowanym świecie? Należy mieć jednak nadzieję, że nie spełni się pewna wizja, do której autora natchnęły plany poprzedniego Naczelnego Dyrektora Archiwów Państwowych. Wizja, w której po zretrokonwertowaniu i otagowaniu całego zasobu, użytkownik w czytelni nie będzie już musiał mieć kontaktu z archiwistą. Obsłuży się sam, za pomocą automatów do zamawiania, znanych głównie z barów szybkich dań i dworców PKP. Złożone zamówienie zrealizuje maszyna bądź w najlepszym razie magazynier niemający większego pojęcia o archiwaliach, którymi się opiekuje (ale także niepotrzebujący takiego pojęcia). Tym samym trzeba mieć nadzieję, że archiwa - będące $\mathrm{z}$ jednej strony prekursorami racjonalizacji, a z drugiej niebędące $\mathrm{w}$ jej awangardzie - będą potrafiły czerpać z niej to, co najlepsze, zachowując jednocześnie swoją niepowtarzalną tożsamość.

\section{Bibliografia}

Laszuk, Anna. „Standardy Międzynarodowej Rady Archiwów - od praktyki do teorii?” W Teoria archiwalna: wczoraj - dziś - jutro, zredagowali Waldemar Chorążyczewski i Agnieszka Rosa, 227-246. Toruńskie Konfrontacje Archiwalne 2. Toruń: Wydawnictwo Naukowe Uniwersytetu Mikołaja Kopernika, 2011.

Love, John F. McDonald's: Behind the Arches. Toronto: Bantam Books, 1986. 
McDonald's Corporation. "McDonald's Reports Fourth Quarter And Full Year 2018 Results And Quarterly Cash Dividend.” Dostęp 04.02.2019. https://mcdonaldscorporation. gcs-web.com/news-releases/news-release-details/mcdonalds-reports-fourth-quarter -and-full-year-2018-results-and.

McDonald's Polska Sp. z o.o. „Informacje o firmie: McDonald's w Polsce: 403 restauracje w ponad 150 miejscowościach, ponad 22500 pracowników i pół miliona gości każdego dnia.” Dostęp 04.02.2019. https://mcdonalds.pl/files/McDonalds_-_informacje_o_firmie.pdf?368.

Naczelna Dyrekcja Archiwów Państwowych. „Protokół z posiedzenia Centralnej Komisji Metodycznej, Warszawa, 7.11.2018 r.” Dostęp 04.02.2019. https://www.archiwa. gov.pl/files/Protokol_posiedzenia_CKM_7_11_2018.pdf.

Naczelna Dyrekcja Archiwów Państwowych. „Zarządzenie nr 24 Naczelnego Dyrektora Archiwów Państwowych z dnia 18 maja 2017 r. w sprawie organizacji udostępniania materiałów archiwalnych w archiwach państwowych.”. Dostęp 22.06.2019. https:// www.archiwa.gov.pl/files/Zarzadzenie_NDAP_18_5_2017.pdf.

Ritzer, George. Makdonaldyzacja społeczeństwa: wydanie na nowy wiek. Przetłumaczył Ludwik Stawowy. Wyd. 5. Warszawa: Warszawskie Wydawnictwo Literackie „Muza”, 2009.

Weber, Max. Gospodarka i społeczeństwo: zarys socjologii rozumiejącej. Przetłumaczyła Dorota Lachowska. Biblioteka Socjologiczna. Warszawa: Wydawnictwo Naukowe PWN, 2002. 
